Diabetologia 10, 323-328 (1974)

(C) by Springer-Verlag 1974

\title{
Effect of Insulin Infusions on the Glucose Kinetics in Alloxan-Streptozotocin Diabetic Dogs*
}

\author{
B. Issekutz, Jr., T.B. Issekutz, D. Elahi and I. Borkow \\ Department of Physiology and Biophysics, Dalhousie University, Halifax, Nova Scotia, Canada
}

Received: December 20, 1973, and in revised form: April 5, 1974

Summary. In diabetic dogs with indwelling catheters, the rates of appearance ( $\mathrm{Ra}$, hepatic glucose output), disappearance ( $\mathrm{Rd})$, and clearance (CR) of glucose were measured with $2{ }^{3} \mathrm{H}$-glucose as tracer according to the primed constant infusion isotope dilution techniques. Permanent diabetes was produced by alloxan $(50 \mathrm{mg} / \mathrm{kg})$ plus streptozotocin $(30 \mathrm{mg} / \mathrm{kg})$. After a two hour equilibrium phase insulin was infused at various rates $(1-2 \cdot 5$ $\mathrm{mU} / \mathrm{kg} \mathrm{min}$ ). The blood glucose lowering effect of $1 \mathrm{mU} / \mathrm{kg}$ min insulin was entirely due to the decrease of the hepatic glucose output. The more rapid decline of plasma glucose during higher rates of insulin infusion were the result of a combined effect of a decreased Ra and increased $\mathrm{Rd}$. There was no correlation between the depression of Ra and the increase of plasma insulin level but there was a significant linear correlation between the latter and the increase of CR. It is concluded that in the diabetic dog, in the presence of $\alpha$-cells, a small rise of plasma insulin level (of $10-20 \mu \mathrm{U} / \mathrm{ml}$ ) already causes the elevated hepatic glucose output to decline to normal values or below. It is suggested that the normally low insulin controls the plasma glucose level by controlling the hepatic glucose production and after a glucose load the elevated insulin restores plasma glucose mainly by increasing the peripheral (including hepatic) utilization of glucose.

Key words: Insulin and glucose turnover, alloxanstreptozotocin diabetes, insulin in chemical diabetes, hepatic effect of insulin, plasma insulin, glucose clearance and insulin.
Almost exactly half a century ago the first study which demonstrated that insulin pretreatment greatly decreased the glucose production and adrenalin sensitivity of the perfused frog liver was published [1]. For a long time the hepatic effect of insulin was ques. tioned, mainly because insulin added to the perfusate did not reduce the rate of glucose production of mammalian livers. In the last two decades, however, many studies were designed with the aim to clarify the hepatic effects of insulin in the intact organism. These investigations can largely be divided into two groups, a) studies based on catheterization of the hepatic vein (HV) and of an artery (A) in man $[2,3,4,5]$ and in the $\operatorname{dog}[6,7]$ with $[3,7]$ or without porta-caval shunt, and b) studies using the radioisotope dilution tracer techniques in diabetic and non-diabetic men [8] as well as in normal $[9,10]$ and pancreatectomized dogs $[11,12]$.

It should be emphasized that the various types of experiments yield different information. Measurements of HV-A (times the hepatic blood flow) are concerned with the participation of the splanchnic area in glucose homeostasis but they are not suitable to study the effect of insulin on hepatic glucose output because the area includes the intestinal as well as large masses of adipose tissues, both of which are highly insulin sensitive [13]. Experiments with porta-caval shunts (even though the hepatic blood flow is only half of the normal) were used successfully to show the effect of insulin (low and high infusion rates) on the net glucose balance across the liver [7], but they can not tell whether insulin increased the hepatic uptake or de-

* Supported by the Medical Research Council of Canada. creased the hepatic output (or both) of glucose. This latter can be measured, theoretically at least, by the radio-isotope dilution method only. The procedure, the most physiological among all, is based on the assumption that the glucose produced by the liver does not carry radioactivity, and therefore the dilution of the tracer by the entering non-radioactive glucose, that is the specific activity, gives the hepatic glucose output. However, the most commonly used tracer, ${ }^{14} \mathrm{C}$-glucose is open to severe criticism (Lit. see Ref. 7), because a) the radio-carbon recycles via gluconeogenesis from $\mathrm{C}_{3}$ units (lactate, alanine, etc.), b) it also labels the outer tiers of liver glycogen [14] and c) it may also enter the hepatic glucose-6-phosphate pool through the action of glucokinase. Therefore, the liver may produce a mixture of ${ }^{12} \mathrm{C}$ and ${ }^{14} \mathrm{C}$-glucose, resulting in the radio-carbon measuring an erroneously low hepatic glucose output. Only a tracer which loses the label while passing through the gl-6-P pool would measure the true flux of glucose from the liver into the plasma. $2{ }^{3} \mathrm{H}$-glucose seems to meet this requirement the best. This isotope loses the tritium in the hexose-isomerase reaction as tritiated water. A single cycle between gl-6-P and fructose-6-P and back removes $75 \%$ of the label from the glucose molecules [15]. Due to the high turnover rate of the hexose-phosphate shuttle (gl-6-P $\rightleftarrows \mathrm{fr}-6-\mathrm{P}$ ) no recycling can occur. Therefore, $2{ }^{3} \mathrm{H}$-glucose as tracer gives $30-34 \%$ higher values for the hepatic glucose output than did ${ }^{14} \mathrm{C}$-glucose (U) [16]. The aim of the present study was a) to use ${ }^{-3} \mathrm{H}$-glucose in estimating the effect of insulin on the hepatic glucose output and on the rate of removal of glucose (this also includes hepatic uptake), and b) to produce diabetes by an 
alloxan-streptozotocin [17] mixture rather than by pancreatectomy. Both compounds were shown to destroy the B-cells and the combination of the two produced permanent diabetes with little nephrotoxic side effects (plasma creatinine $<2 \mathrm{mg} / 100 \mathrm{ml}$ ). The importance of this type of diabetes as opposed to pancreatectomy as a model for diabetes mellitus was recently underlined by the finding that in alloxan dia. betic dogs the plasma glucagon level is elevated and
Chow together with $200 \mathrm{~g}$ meat daily. In light Pentothal anesthesia, polyethylene indwelling catheters were placed in the left jugular vein and carotid artery. The dogs were trained to lie quietly for about $5 \mathrm{~h}$. After a $24 \mathrm{~h}$ fasting period $50 \mathrm{mg} / \mathrm{kg}$ alloxan (Eastman) and $30 \mathrm{mg} / \mathrm{kg}$ streptozotocin (Upjohn) were administered. Forty-eight $\mathrm{h}$ later insulin (protamin-zinc, $1-1.5 \mathrm{U} / \mathrm{kg}$ ) treatment was introduced to keep the urine free of glucose and $48-60 \mathrm{~h}$ before the experi-
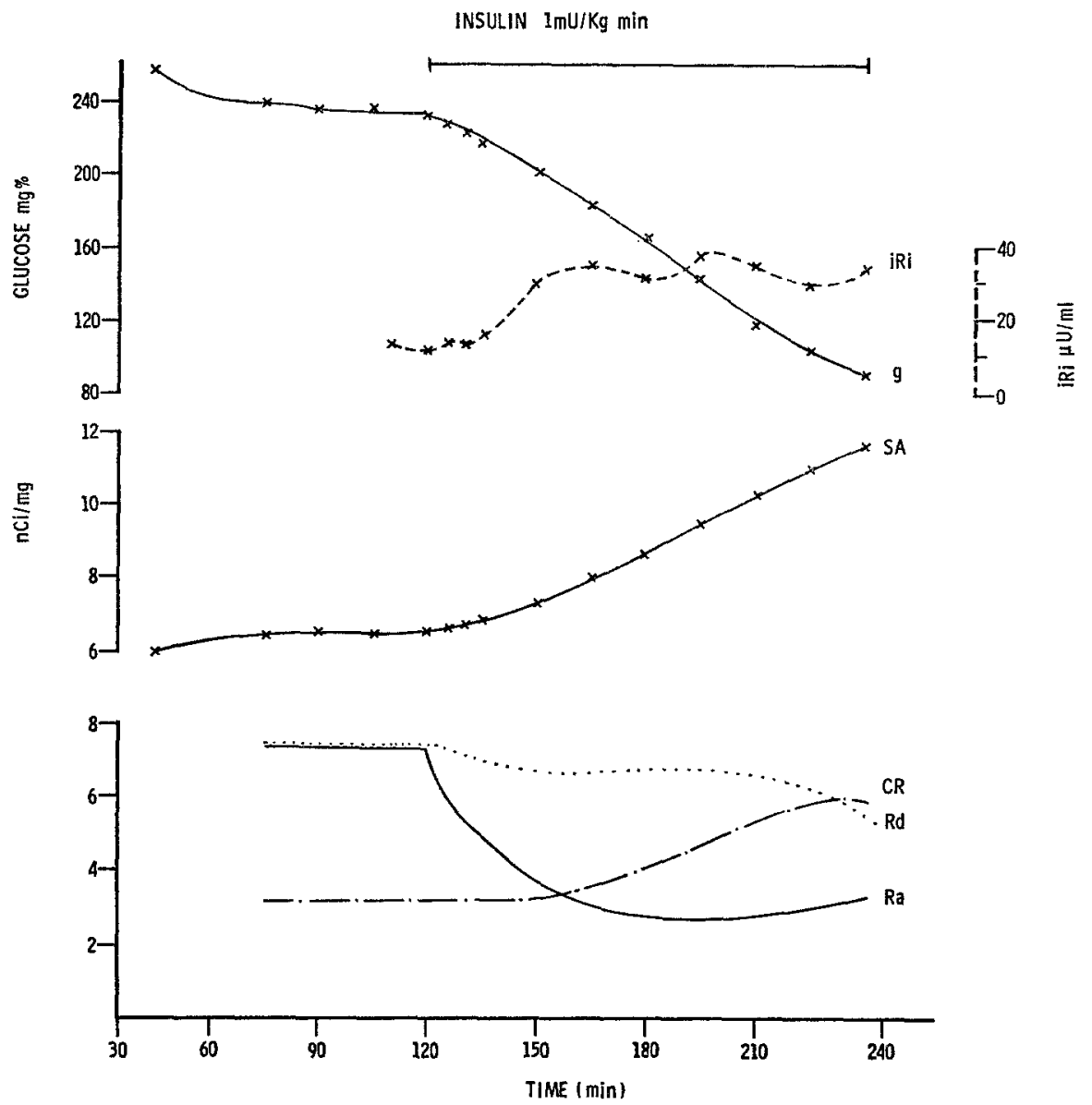

Fig. 1. Effect of $1 \mathrm{mU} / \mathrm{kg}$ min insulin $\left(t_{120}-t_{240}\right)$ on the glucose kinetics of an alloxan-streptozotocin treated dog "g": plasma glucose (mg \%); iRi $(\times-\times)$ : immunoreactive insulin $(\mu \mathrm{U} / \mathrm{ml})$; SA: glucose specific activity (nCi/mg); Ra (continuous line); Rd (dotted line); rates of appearance and disappearance, respectively (mg/kg $\mathrm{min})$; CR (-.-.-) : clearance rate of glucose $(\mathrm{ml} / \mathrm{kg} \mathrm{min})$

insulin infusion quickly restored it to normal [18]. In addition, insulin was infused at various rates and an attempt was made to correlate the effect on hepatic glucose output as well as the peripheral response with plasma insulin levels.

\section{Methods}

Thirteen experiments were conducted on 8 dogs of $12-18 \mathrm{~kg}$ body weight. The dogs were fed Purina Dog ment a short acting preparation was given (0.5$0.8 \mathrm{U} / \mathrm{kg}$ ). The experiment was preceded by $18 \mathrm{~h}$ fasting. At zero time a priming dose of $3-4 \mu \mathrm{Ci} / \mathrm{kg} 2{ }^{3} \mathrm{H}-$ glucose was given i.v. followed by a constant rate infusion of $30-40 \mathrm{nCi} / \mathrm{kg}$ min. Arterial samples were collected at $t=45,75,90,105$ and 120 min to obtain base line values. At $t=120$ a $2 \mathrm{~h}$ infusion of glucagonfree insulin $(1-5 \mathrm{mU} / \mathrm{kg} \mathrm{min})$ was started. Samples were taken at $t=125,130,135$ and then every $15 \mathrm{~min}$ until $\mathrm{t}=\mathbf{2 4 0}$. 


\section{Analytical Procedures}

The blood was collected in chilled tubes, centrifuged and the plasma proteins were precipitated with $\mathrm{Ba}(\mathrm{OH})_{2}$ and $\mathrm{ZnSO}_{4}$. The precipitate was centrifuged, and $2 \mathrm{ml}$ aliquots of the supernatant were evaporated to dryness in a vacuum at $75^{\circ} \mathrm{C}$ to eliminate the ${ }^{3} \mathrm{H}_{2} \mathrm{O}$ in the plasma. The residue was dissolved in $1 \mathrm{ml} \mathrm{H}_{2} \mathrm{O}$ and counted in Aquasol (Now England Nuclear). Aliquots of the same supernatant were used for glu-
Where " $F$ " is the infusion rate (nCi//kg min) of the tracer, $\mathrm{dSA} / \mathrm{dt}$ and $\mathrm{dg} / \mathrm{dt}$ are derivatives of the polynomials which describe the course of SA and " $g$ " (plasma glucose, $\mathrm{mg} / \mathrm{ml}$ ), respectively. In dynamic steady state $\left(t_{0}-t_{120}\right) d S A / d t$ and $d g / d t \simeq 0$ and the turnover rate $(\mathrm{Ra} \simeq \mathrm{Rd})=\mathrm{F} / \mathrm{SA}$. In non-steady state if enough data are available (degree of freedom 7 or 8 ) one can easily find the best fitting polynomial. This method has two advantages over the more commonly

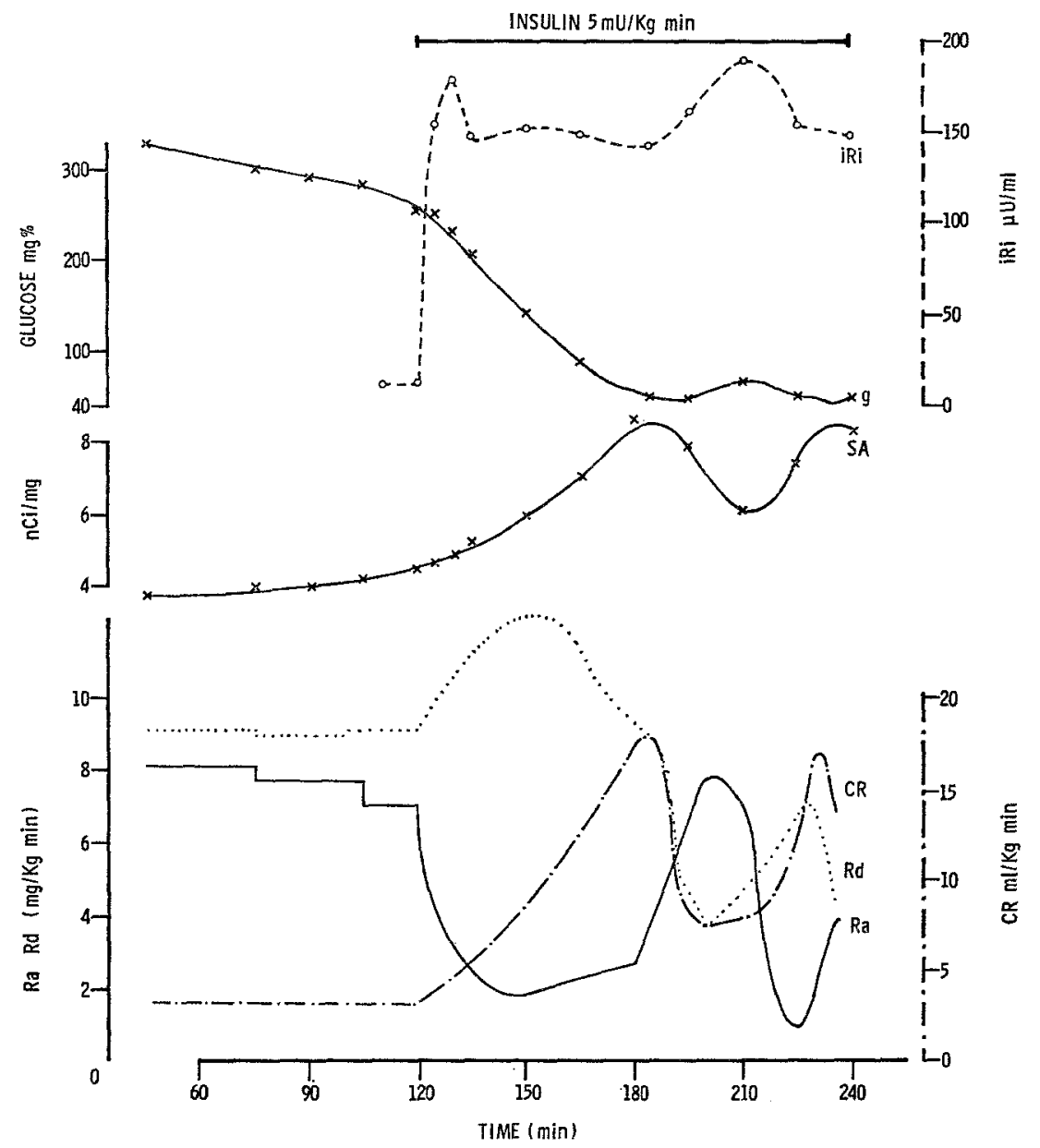

Fig. 2. Effect of $5 \mathrm{mU} / \mathrm{kg}$ min $\left(t_{120}-t_{240}\right)$ of insulin on the glucose kinetics of an alloxan diabetic dog. Symbols are as in Fig. 1

cose determination (glucose oxidase method), and the specific activity of glucose (SA) was expressed in $\mathrm{nCi} /$ $\mathrm{mg}$. The radioimmunoassay of insulin was based on the double antibody method of Hales and Randle [19].

\section{Calculations}

The rates of appearance ( $\mathrm{Ra}, \mathrm{mg} / \mathrm{kg} \mathrm{min})$ and disappearance of glucose $(\mathrm{Rd})$ were calculated according to Steele [20].

$$
R a=\frac{F-V g \frac{d S A}{d t}}{S A} \text { and } R d=R a-V d g / d t
$$

used interval calculation: (a) it does not consider the measured values errorless (degree of freedom $=0$ ), and (b) it describes the course of Ra and Rd in the form of continuous curves and the values do not depend on the length of the interval between samples. A polynomial was accepted if the largest deviation from the measured values was nowhere more than $\pm 3 \%$. " $V$ " represents the "miscible space" in which the changes of SA and " $g$ " take place. Our previous studies [21] showed that when a perturbation of the steady state begins (in this case due to the infusion of insulin) " $V$ "' is smaller than the total volume of distribution of glucose (about 
$300 \mathrm{ml} / \mathrm{kg}$ ) and it increases asymtotically according to a single exponential equation: $V_{\tau}=303-167.6 \mathrm{e}^{-0.046 \tau}$. Where $\tau$ is the time (min) from the start of the insulin infusion $(=t-120)$.

Finally, the clearance rate of glucose CR $(\mathrm{ml} / \mathrm{kg}$ $\mathrm{min})==\mathrm{Rd} / \mathrm{g}$ was calculated. At normoglycemia this value is called the "metabolic clearance rate" [22] and is a useful index of the ability of the tissues to remove glucose. In diabetic hyperglycemia it includes also the renal loss of glucose, nevertheless it proved to give valuable information concerning the peripheral effect of insulin.

\section{Results}

Fig. 1 shows the response of a diabetic dog to a slow $(1 \mathrm{mU} / \mathrm{kg} \mathrm{min})$ infusion of insulin which caused about $20-25 \mu \mathrm{U} / \mathrm{ml}$ increase in the plasma immuno-
Interestingly, with the increase of the hepatic glucose output the $\mathrm{CR}$ also decreased. In other words, the effect of insulin was temporarily overcome at the level of production as well as at that of utilization. The effect of the insulin hypoglycemia on Ra has long been recognized by many investigators $[3,5,8]$. Less is known about the cause of the decrease of CR due to hypoglycemia. This could be the result of the well known rise of the growth hormone level in hypoglycemia, with the concomitant inhibition of the effect of insulin on the utilization of glucose [23], or that of the increase of plasma adrenalin known to enhance glycogenolysis and to inhibit the insulin stimulated glucose uptake of the skeletal muscle [24].

The $-5 \mathrm{mU} / \mathrm{kg} \mathrm{min}$ infusion rate decreased plasma glucose more rapidly than $1 \mathrm{mU} / \mathrm{kg} \min$ (Table 1 ). Values obtained after $45 \mathrm{~min}$ of infusion showed that this difference was mainly due to the significantly greater increase of $\operatorname{Rd}(p<0.01)$ and the $\mathrm{CR}(p<0.02)$,

Tablo 1. Effect of insulin infusions on glucose kinetics as measured after 45 min in diabetic dogs

\begin{tabular}{|c|c|c|c|c|}
\hline & $\begin{array}{l}\text { Base line } \\
\text { values }\end{array}$ & $\begin{array}{l}\text { Changes }(\Delta) \\
1 \mathrm{mU} / \mathrm{kg} \mathrm{min}\end{array}$ & $\begin{array}{l}\text { due to insulin of } \\
2-5 \mathrm{mU} / \mathrm{kg} \text { min }\end{array}$ & $\mathbf{p}^{\mathrm{a}}<$ \\
\hline $\begin{array}{l}\mathrm{iRi} \\
\mu \mathrm{U} / \mathrm{ml}\end{array}$ & - & $17.4(3.5)^{\mathrm{b}}$ & $93.6(22.8)$ & 0.01 \\
\hline $\begin{array}{l}\text { glucose } \\
\mathrm{mg} \%\end{array}$ & $294 \quad(27.3)$ & $-40 \quad(3.3)$ & $-104 \quad(18.6)$ & 0.01 \\
\hline $\begin{array}{l}\mathrm{Ra} \\
\mathrm{mg} / \mathrm{kg} \min \end{array}$ & $6.7 \quad(1.7)$ & $-2.9(0.3)$ & $-2.7 \quad(0.5)$ & N.S. \\
\hline $\begin{array}{l}\mathrm{Rd} \\
\mathrm{mg} / \mathrm{kg} \min \end{array}$ & $8.0 \quad(0.6)$ & $\rightarrow 0.9(0.4)$ & $+2.0 \quad(0.6)$ & 0.01 \\
\hline $\begin{array}{l}\mathrm{CR} \\
\mathrm{ml} / \mathrm{kg} \min \end{array}$ & $2.9 \quad(0.2)$ & $+0.1(0.1)$ & $+6.5 \quad(1.8)$ & 0.02 \\
\hline $\mathbf{n}$ & 12 & 6 & 6 & 一 \\
\hline
\end{tabular}

a Significance of the difference between 1 and $2-5 \mathrm{mU} / \mathrm{kg} \mathrm{min}$ of insulin

$\mathrm{b}$ (土 SEM)

reactive insulin (iRi). The slow decline of plasma glucose from $230 \mathrm{mg} / 100 \mathrm{ml}$ to $90 \mathrm{mg} / 100 \mathrm{ml}$ is accompanied by a similar slow rise of $\mathrm{SA}$ indicating the decreasing dilution of the tracer by unlabelled glucose, that is, a decrease of Ra. Rd did not rise at all and the decrease of blood glucose had to be ascribed entirely to the hepatic effect of insulin.

The peripheral effect is revealed by the slow rise of the clearance (CR). Nevertheless, there was no evidence of any increase of $\mathrm{CR}$ in the first $40 \mathrm{~min}$ during which time plasma glucose declined by $43 \mathrm{mg} \%$. The effect of a more rapid insulin infusion ( $5 \mathrm{mU} / \mathrm{kg} \mathrm{min}$ ) is shown in Fig. 2. Within 5 min plasma iRi rose by $150 \mu \mathrm{U} / \mathrm{ml}$. The rapid decline of plasma glucose was due to both a sharp decrease of Ra and a rise of Rd. The six-fold increase of CR clearly shows the greatly enhanced ability of the tissues to remove glucose from the plasma. This experiment also shows the secondary transient response to insulin hypoglycemia. When plasma glucose reached about $40 \mathrm{mg} \% \mathrm{SA}$ started to decline, indicating a rather rapid increase of $\mathrm{Ra}$. This along with the decrease of Rd raised the plasma glucose to $70 \mathrm{mg} \%$. while the effect of the hepatic (Ra) output was not significantly different whether the immunoreactive insulin rose by 17.4 or by $93.6 \mu \mathrm{U} / \mathrm{ml}$.

The relative importance of the hepatic versus peripheral effect of insulin can clearly be seen if the changes of $\mathrm{Ra}, \mathrm{Rd}$, and $\mathrm{CR}$ ( $\Delta$ values) are plotted against the changes of plasma glucose (Fig. 3). This seems to indicate that insulin infused at a rate of $1 \mathrm{mU} / \mathrm{kg} \min$ (continuous lines), lowers the plasma glucose level only by decreasing the hepatic production of glucose, the peripheral effect plays a role only when the infusion rate is higher (broken lines). The increased ability of the tissues to remove glucose seems to be responsible for the more rapid decrease of plasma glucose in this latter group.

Apparently the livers of these animals are extremely sensitive to insulin and, therefore, no correlation was found between $\triangle \mathrm{Ra}$ and $\Delta \mathrm{iRi}$. On the other hand, there was a highly significant linear correlation between the $\triangle \mathrm{CR}$ and $\Delta \mathrm{iRi}$ which could be described by the equation: $\Delta \mathrm{CR}=0.057 \Delta \mathrm{iRi}-0.16(\mathrm{n}=11, \mathrm{r}=$ $0.906, P<0.001$ ). 


\section{Discussion}

The most important difference between a pancreatectomized and an alloxan diabetic dog is that the latter has a functioning and apparently excessively working A-cell system. From that point of view, the chemically induced diabetes resembles the diabetes mellitus found in man more than the diabetes caused by pancreatectomy. Müller et al. [18] reported that blockade of glucose metabolism by 2-deoxy-glucose or experimentally induced insulin deficiency (mannoheptulose, anti-insulin serum, alloxan-diabetes) increased

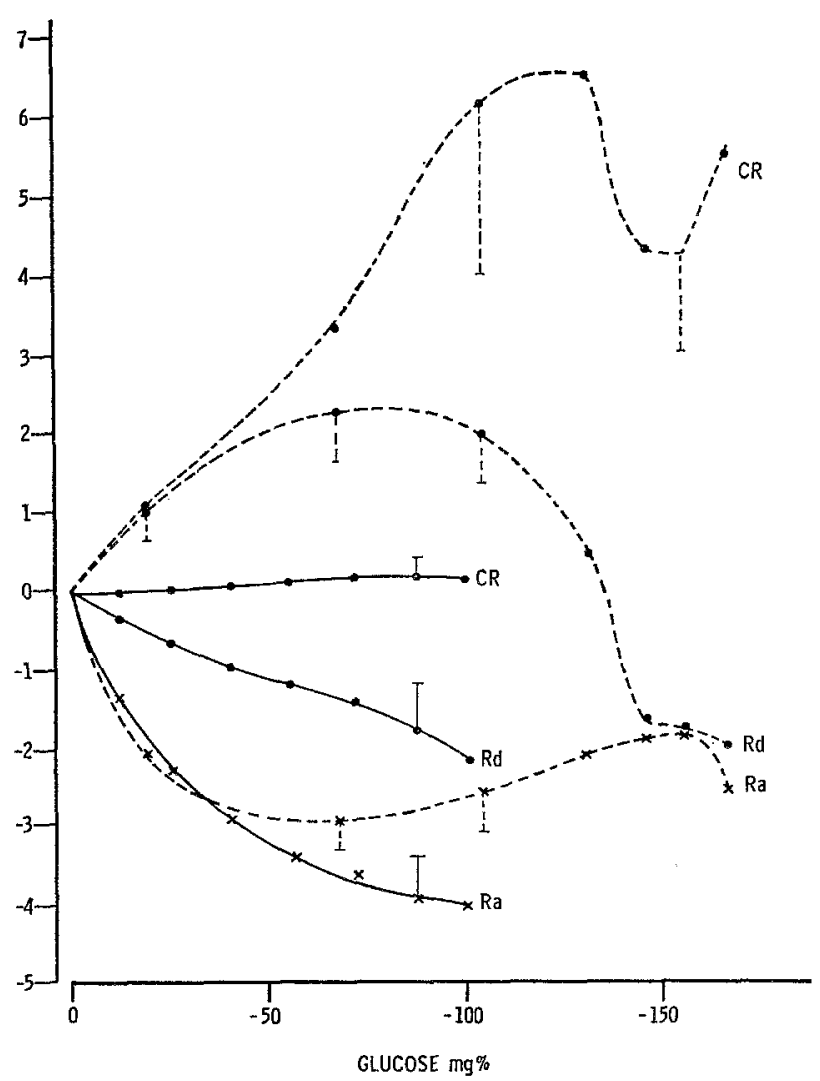

Fig. 3. A comparison of the effects of $1 \mathrm{mU} / \mathrm{kg} \mathrm{min}$ (continuous lines) and $2-5 \mathrm{mU} / \mathrm{kg} \mathrm{min}$ (broken lines) of insulin infusions. Relationships between changes $(\Delta$ values) of plasma glucose (abscissa) and Ra, Rd and CR (ordinate). Each line is the mean of six experiments vertical lines S.E. of the means. Ra and $\mathrm{Rd}$ in $\Delta \mathrm{mg} / \mathrm{kg}$ $\mathrm{min}$ and $\mathrm{CR}$ in $\Delta \mathrm{ml} / \mathrm{kg} \mathrm{min}$

the plasma glucagon level. The hypothesis was put forward that normal glucose metabolism in the A-cell is an insulin requiring process. Furthermore, on the perfused rat liver insulin added to the perfusate in physiological concentrations strikingly inhibited the glucagon stimulated glucose production [25]. This effect was accompanied by a reduction of cyclic AMP release by the liver. In the absence of glucagon insulin failed to inhibit the glucose output.
These observations readily explain the strong hepatic effect of insulin in the alloxan-streptozotocin treated dogs. When insulin was infused at a slow rate $(1 \mathrm{mU} / \mathrm{kg} \mathrm{min})$ it was possible to decrease plasma glucose by $100 \mathrm{mg} \%$ essentially without any peripheral effect. Such a low infusion rate raises plasma insulin only by $10-30 \mu \mathrm{U} / \mathrm{ml}$ indicating that the hepatic effect of insulin, possibly mediated or accentuated by a decrease of glucagon release by the A-cells [12], plays a more important role in the normal regulation of blood glucose concentration than does the peripheral effect. This latter seems to require a higher concentration of insulin and it increases proportionally with the plasma insulin levels. The more rapid decline of plasma glucose at higher insulin infusions is mainly due to the increase of CR. It should be pointed out that in the diabetic animal CR is the sum of the metabolic clearance rate and the renal clearance rate. As plasma glucose decreases, due to insulin, the renal clearance approaches zero therefore the increase of the metabolic clearance is slightly higher than the rise of the total CR. In summary, the conclusion seems to be justified that the normally low plasma insulin controls the glucose level by controlling the hepatic glucose output (possibly by regulating glucagon production) while after a glucose load (food intake) the highly elevated insulin restores the glucose concentration mainly by increasing the peripheral (including hepatic) uptake of the excess glucose. A generally similar conclusion was reached from measurements of net glucose balances across the liver [6]. There is, however, an important difference: while the net balance may become zero or it may even show a net hepatic uptake of glucose, the isotope dilution experiments (with $2{ }^{3} \mathrm{H}$-glucose as tracer) clearly indicate that insulin cannot stop the hepatic output of glucose possibly because glucagon and cAMP do not seem to be involved in the glucokinase-glucose-6-phosphatase pathway (gl $\rightarrow$ gl-6-P $\rightarrow$ gl).

\section{References}

1. v. Issekutz, B.: Beiträge zur Wirkung des Insulins. Biochem. Z. 147, 264-274 (1924)

2. Bearn, A.G., Billing, B.H., Sherlock, S.: The response of the liver to insulin in normal subjects and in diabetes mellitus: Hepatic vein catheterisation studies Clin. Sci. 11, 151-165 (1952)

3. Craig, J.W., Drucker, M., Miller, M., Woodward, Jr., H.: The prompt effect of exogenous insulin on net hepatic glucose output in man. Metabolism 10, 212$220(1961)$

4. Felig, P., Wahren, J.: Influence of endogenous insulin secretion on splanchnic glucose and amino-acid metabolism in man. J. clin. Invest. 50, 1702-1711 (1971)

5. Wahren, J., Felig, P., Cerasi, E., Luft, R.: Splanchnic and peripheral glucose and aminoacid metabolism in diabetes mellitus. J. clin. Invest. 51, 1870-1877 (1972)

6. Madison, L.L.: Role of insulin in the hepatic handling of glucose. Arch. Intern. Med. 123, 284-292 (1969) 
7. Madison, L.L., Combes, B., Adams, R., Strickland, W.: The physiological significance of the secretion of endogenous insulin into the portal circulation. IIT. Evidence for a direct immediate effect of insulin on the balance of glucose across the liver. J. clin. Invest. 39, 507-522 (1960)

8. Kalant, N., Csorba, T.R., Heller, N.: Effect of insulin on glucose production and utilisation in diabetes. Metabolism 12, 1100-1111 (1963)

9. Dunn, D.F., Friedmann, B., Maass, A.R., Reichard, G.A., Weinhouse, S.: Effects of insulin on blood glucose entry and removal rates in normal dogs. $J$. biol. Chem. 225, 225-237 (1957)

10. Steele, R., Bishop, J.S., Dunn, A., Altszuler, N., Rathgeb, I., de Bodo, R.C.: Inhibition by insulin of hepatic glucose production in the normal dog. Amer. J. Physiol. 208, 301-306 (1965)

11. Henderson, M.J., Wrenshall, G.A., Odense, P.: Effects of insulin on rates of glucose transfer in the depancroatized dog. Canad. J. Biochem. 33, 926-939 (1955)

12. Hetenyi, Jr., G., Wrenshall, G.A., Best, C.H.: Rates of production, utilization, accumulation and apparent distribution space of glucose. Diabetes 10, 304-311 (1961)

13. Shoemaker, W.C., Mahler, R., Ashmore, J.: The effect of insulin on hepatic glucose metabolism in unaesthetized dogs. Metabolism 8, 494-511 (1959)

14. Landau, B.R., Leonards, J.R.: Significance of changes in blood glucose specific activity following insulin administration. Amor. J. Physiol. 198, 793796 (1960)

15. Katz, J., Dunn, A.: Glucose-2-T as a tracer for glucose metabolism. Biochemistry 6,1-5 (1967)

16. Issekutz, Jr., B., Allen, M., Borkow, I.: Estimation of glucose turnover in the dog with 2-T-glucose and glucose-U.14C. Amer. J. Physiol. 223, 710 - 712 (1972)
17. Rakieten, N., Rakieten, M.L., Nadkarni, V.: Studies on the diabetogenic action of streptozotocin (NSC37917). Cancer Chemother. Rep. 29, 91-98 (1963)

18. Mïller, W.A., Faloona, G.R., Unger, R.H.: The effect of experimental insulin deficiency on glucagon secretion. J. clin. Invest. 50, $1992-1999$ (1971)

19. Hales, C.N., Randle, P.J.: Immunoassay of insulin. with insulin antibody precipitate. Lancet $1963 \mathrm{I}, 200$

20. Steele, R.: Influences of glucose loading and of injected insulin on hepatic glucose output. Ann. N.Y. Acad. Sci. 82, 420-430 (1959)

21. Issekutz, T.B., Issekutz, Jr., B., Elahi, D.: Estimation of hepatic glucose output in nonsteady state. The simultaneous use of $2{ }^{3} \mathrm{H}$-glucose and ${ }^{14} \mathrm{C}$-glucose in the dog. Canad. J. Physiol. Pharm. 52, (1974)

22. Riggs, D.S.: The mathematical approach to physiological problems. Baltimore: Williams and Wilkins 1963

23. Bishop, J.S., Steele, R., Altszuler, N., Rathgeb, I., Bjerknes, C, de Bodo, R.C.: Diminished responsiveness to insulin in the growth hormone-treated normal dog. Amer. J. Physiol, 212, $272-278$ (1967)

24. Groen, J., Geld, H., Bolinger, R.E., Willebrands, A.F.: The anti-insulin effect of epinephrine. Its significance for the determination of serum insulin by the rat diaphragm method. Diabetes 7, 272-277 (1958)

25. Exton, J.H., Lewis, S.B., Ho, R.J., Park, C.R.: The role of cyclic AMP in the control of hepatic glucose production by glucagon and insulin. Advanc. Cyclic Nucleotide Res. 1, 91-101 (1972)

Professor Dr. B. Issekutz, Jr.

Dalhousie University

Dept. of Physiology and Biophysics

Faculty of Medicine

Halifax, N.S.

Canada 